\title{
HORACE ON HORACE ODES 4
}

\author{
S Thom (University of Stellenbosch)
}

Horace's fourth Book of Odes was published in 13 B.C. ${ }^{1}$ Ten years had passed since the publication of Odes 1-3. In Epistles 1.1.4 published 7 years before Odes 4 Horace already indicated that for him neither age nor mind was the same (non eadem est aetas, non mens, Epistles 1.1.17) and that a wise person (sanus) would turn the aging horse to pasture (solve senescentem mature sanus equum, Epistles 1.1.8). It is clear then that Horace would have needed some serious inducement to return from that pasture of retirement into the fray of committing himself to writing lyric poetry and especially odes again.

This paper agrees with i.a. Putnam that critics have often underestimated the achievement represented by Odes $4 .^{2}$ And if the artistic achievement of Odes 4 is accepted, then justification for the existence of the collection seems to be self-evident, in spite of Horace's clear reluctance to write the poems contained in the collection. ${ }^{3}$ When we turn to Odes 4 it seems reasonable to assume that - amongst other things the opportunity to reassess his stance on matters with which he had been preoccupied in Odes 1-3 posed a challenge which Horace in the end could not resist. ${ }^{4}$ For without very specific inducement to return to writing odes again Horace could have remained out to pasture as he indicated in Epistle 1.1. Why did it make good sense to add Odes

1 See Putnam (1986:23 n. 6) why 13 BC instead of 8 BC should be preferred and Armstrong (1980:154) why a date as early as the late 20's is possible. Cf. Becker (1963:190) for a list of possible dates for individual poems.

2 Ten years later Barchiesi (1996:6) still refers to the need for a "reevaluation of this underestimated book of poetry." Currie (1996:78) gives a whole list of critics whose descriptions collectively reflected Odes 4 as containing "some of the most flat or frigid or prosaic stanzas in the poet's lyric output."

3 Unfortunately the necessity of establishing the need for a collection such as Odes 4 (as is reflected in practically every critical work which deals with Odes 4) implies that, in spite of more, or less, appreciation for the work, the collection is somehow superfluous.

4 I see Horace's achievement in Odes 4 in a much more creative light - a development of his thought rather than a simple "reexamination [in Odes 4] of the collection it concludes" (Putnam 1986:26). Yet, to a certain extent some reexamination of Odes 1-3 is inevitable, given the passage of time between publications of this book and the previous collection. Moreover certain themes represent a lifelong artistic and intellectual interest. One would expect Horace to return to them and develop them rather than to reflect on subject matter that has not appealed to him before. Cf. for instance Skinner (in Tulley 1988:274) who maintains that "...to argue is always to argue for or against a certain assumption or point or view or course of action." 
4 to the existing collection of odes $^{5}$ - apart from giving further proof of artistic excellence? $^{6}$

In this, one of his last publications, ${ }^{7}$ Horace, not quite unexpectedly, directs his attention to some of the main themes reflected in Odes 1-3. Treating these themes yet again in Odes 4 would only make artistic sense if Horace had felt the need to reassess his original position on the content or if he had hoped to improve on the form. In other words Odes 4 would only have been necessary if Horace had planned to rewrite Horace in some way. ${ }^{8}$ If, however, Horace's primary aim in Odes 4 is not to reassess what he has done in a previous collection (even though he does some of this), if it is not to give yet another display of artistic brilliance, what then was it that overcame his clear reluctance to recommence writing lyric verse? Since Odes 4 commences with a clear indication of this reluctance, it seems plausible that Odes 4 itself should then also indicate how and why this reluctance was overcome. ${ }^{9}$

One of the first impressions that strikes the reader of Odes 4 is the omission of a dedication to Maecenas. After all, the first Satire, the first Epode, the first Ode and the first Epistle were all dedicated to Maecenas. Very positive mention is made of Maecenas in Odes 4.11 17-18, however, where Horace refers to Maecenas's birthday as "a festive day for me and almost more special than my own birthday" ([dies] iure sollemnis mihi sanctiorque paene natali proprio). This omission of a dedication to Maecenas is fundamental for understanding why Odes 4 was written at all. It indicates that Odes 4.1 is not intended as a new beginning, but functions rather as a

5 The very fact that critics speculate about Horace's reasons for writing the collection at all (as opposed to why the collection justified its own exixtence) implies that the collection should, maybe, not have been written. It is obvious that the poems themselves will have to supply the evidence for the necessity of their existence.

6 Given the shear effort of composition and Horace's meticulousness, it does not seem feasible that he wrote Odes 4 merely to see if he could still manage to write good poetry. Neither do I accept that Odes 4 owes its exsistence solely to such external occurences as the appearance of works by Virgil and Propertius in the time that has lapsed since the publication of Odes 1-3 (Putnam: 1986: 26) or because of a gratifying response to "the production of the Carmen Saeculare and the circumstances connected with it" (Fraenkel 1957: 410). Neither does it make sense that the encouragement of Augustus alone would have persuaded Horace to take up writing lyric poetry again (Fraenkel 1957:364). Having decided to write Odes 4 the opportunity to react to the publications concerned was not ignored, however (Putnam 1986: 26-28), neither was the production of the Carmen Saeculare or Augustus's encouragement completely irrelevant. If we turn to Odes 4 itself it is clear that the decision to write this book is not based on these circumstances only.

7 The date of the Ars Poetica is variously given as either $20 \mathrm{BC}$ or $13 \mathrm{BC}$ or even later and the second book of Epistles is now thought to belong to the period 20-12 BC.

8 Furthermore, since Horace had already based his claim to fame in Odes 3.30 on mastery of form, further display of his prowess in this area was unnecessary. It is also evident from the very beginning of Odes 4 that Horace's mastery of form as reflected in the first collection of odes has not been impaired in any way.

9 According to Collinge (1961:42) "[i]t is very likely indeed that Horace felt that the heterogeneous (and so much less subtle) fourth book - with personal poems, 'sparked off' by the Carmen Saeculare and belated fame as a lyricist, Augustan commissions, and reworkings of earlier ideas set cheek by jowl - that such a collection needed careful articulation." 
continuation of the previous collection of odes. In this way a clear connection between Odes 1-3 and Odes 4 is forged, in spite of the lapse of 10 years since publication of the first three volumes of odes. This connection between Odes 4 and the previous odes supports the idea that if, in addition, the same topics occur in odes published 10 years later, the poet felt the need to express himself again on such topics, to avail himself of the opportunity for reassessment, to rewrite or add to what he had written previously.

In the introductory odes of the previous three books of odes no unwilling poet is depicted. In each case the poet works in close conjunction with his muse or muses. In Odes 1.1 an exhuberant Horace proclaims that ivy, the poet's reward, links him to the gods (me doctarum hederae praemia frontium dis miscent superis, 1.1.29-30). In Odes 2.1 the lyric poet, aware of the Muse's recklessness (Musa precox, 2.1.37) warns against concentrating on a quest filled with dangerous uncertainty (periculosae plenum opus aleae, 2.1.6). It is up to the lyric poet to keep the distinctions between poetry on war and poetry on lighter themes clear, as well as underlining the advantages generated by the lyric poet's work which concentrates on the latter. ${ }^{10} \mathrm{In}$ Odes 3.1 Horace goes as far as calling himself the Muses' priest (musarum sacerdos, 3.1.3) who sings songs as yet unheard (carmina non prius audita (Odes 3.1.2-3). Here the lyric poet functions as an intermediary between the lyric and the epic world, reinterpreting and making sense of the epic world in terms of a lyric perspective.

In Odes 4.1, however, there is no mention made of the poet's muse. The invocation which introduces this new collection is to Venus, the goddess of love, the harsh mother of sweet Cupids (mater saeva cupidinum dulcium, 4.1.4-5). ${ }^{11}$ Here Venus is the hard taskmaster who forces Horace back into battle. One gets an impression of extreme reluctance on the part of Horace. He confronts Venus, but has to bow to the inevitable. ${ }^{12}$ In Odes 1-3, however, the introductory odes of each book

10 Someone like Pollio who writes about the causas belli (2.1.2) of the civil war needs to tread lightly over fires hidden beneath ashes that can spring to light at the least disturbance (incedis per ignes suppositos cineri dolosa, 2.1.38-40). The lyric poet treads no such dangerous paths. Cf. Barchiesi (1996:30) on the appropriation of epic themes by lyric poets: "The lyric and elegiac appropration of grand epic continues from Pindar and Simonides to Horace..."

11 The mater saeva Cupidum [as well as the metre] of the opening ode of Odes 4 of course refers the reader directly to the introductory mater saeva Cupidum of Odes 1.19.1. At the end of the latter, however, there was a possibility that the goddess could be lenior (more lenient, less intractible, 1.19.16) indicating, at least at that stage, some hope for a better outcome in future. Odes 4.1 ends with an insubstantial Horace (ego...volubilis, 4.1.40) ineffectually tracking a hardhearted and stubborn Ligurinus (dure, 4.1.40). Odes 4.1 echoes Odes 3.26 even more directly in its content, since Horace found himself in the same position in Odes 3.26 as in Odes 4.1: not prepared to re-enter into battle for Venus's sake. See Putnam (1986:42) and Davis (1991:65-66) for a more detailed discussion of the echoes of Odes 3.26 in Odes 4.1.

12 To my mind Syndikus (1973:285) succeeds best in reflecting Horace's position at the beginning of Odes 4 by pointing out that Horace does not propose a renewed personal reawakening of love ("Liebesfrühling"), that the equivocation between re-entering into the fray and refusal to do so takes place on a literary level in the first place ("ist in erster Linie literarisches Spiel") and finally that the love-motif needs to be rekindled since lyric poetry without love is unthinkable, or as Kiessling had already put it (1958:386) "[d]a für den Sänger der convivia et proelia virginum 
repeatedly underlined the Muse's support for Horace. He worked with the muse, he did not have to be forced into his role as poet.

In Odes 4.1 Horace deliberately underplays any special claim he might have had as poet, by concentrating on the awkwardness of the individual who finds himself in a position where he has to pick up where - 10 years previously - he had thought he had reached the pinnacle of his powers (lauro cinge volens, Melpomene, comam, 3.30.16). The focus on the individual and his changing circumstances over the years prepares the reader for the idea of yet another change in perspective, given that change is such a fundamental fact of life. Horace indeed underlines the changes which have taken place in himself. He is not the man he used to be (non sum qualis eram, 4.1.3), which at first glance would make him unfit or which would even seem to fan his reluctance for writing poetry. Aging, moreover, has had a two-pronged effect. At 50 he might not be so agile anymore, but neither is he as persuadable. He describes himself as oblivious (durum, 4.1.6) to Venus's soft enticements (mollibus imperiis, 4.1.7), reluctant to give way to the goddess because he knows what is demanded from him. ${ }^{13}$ It seems as if the dilemma facing Horace is the same he periodically faced in the previous books of odes. As lyric poet he insisted that his talent was for singing of less serious themes (cantamus...non praeter solitum leves, 1.6.19-20). Now Venus forces him into the serious business of bearing her standard. It remains to be seen if the poet sidesteps this coercion with a recusatio, as he has done to requests of the same kind in the past, or if he comes up with still another response. $^{14}$

In this first poem of Odes 4 Horace sets the tone for the rest of the book, namely that things have changed and are therefore in need of reconsideration. ${ }^{15} \mathrm{We}$ have already seen that Horace is quite explicit about his reluctance to commit himself to Odes 4 (non sum qualis eram, 4.1.3). Since he is not in a position to refuse however, (parce, precor, precor, 4.1.2) the very action of having to write seems to beguile him into writing some serious poetry - suggesting that Venus's (and incidentally Augustus's) coercion was not really needed, since some other force had already been brought to bear on Horace.

Dichten und Lieben eins ist, begründet das Wideraufleben der erotischen Stimmung zugleich die Wiederaufnahme des Lyrik." Cf. Habinek (1986:407-16) for an overview of the use of literary conventions in this ode.

13 Horace, however, deliberately uses exactly the same word (durus) to describe his newest love interest, Ligurinus, in a stunning chiasme which places Ligurine in 4.1.33 and its agreeing adjective (dure) 7 lines further in 4.1.40. Cf. also Oliensis (1991:120) for the negative associations implicit in such a prayer to Venus which mirrors a former prayer to Canidia (Epodes 17) so closely.

14 It takes three entire odes before Horace, in gratitude, again acknowleges his debt to his muse: totum muneris hoc tui est (4.3.21) and si placeo, tuum est (4.3.24).

15 At the beginning of Odes 4 Horace explicitly rejects what he previously (Odes 1-3) has praised (love, wine and sharing feasts in friendship (4.1.29-32). Cf. Syndikus on the poet's creating this emphatic distance from the past (1973:293). Cf. also Coffta (1998:28-29) on the tension between the "plain and the grand styles" reflected in the Odes as a whole. 
Closely related to this introductory statement of intent, Horace focuses on the poet's role as poet. This includes aspects such as the poet and his muse, the poet's gift to create poetry which escapes the ravages of time, the poet as man which includes two of Horace's most pervasive themes namely that of carpe diem and love. In short all these aspects could be grouped together under four major themes to be be treated in this final book - themes which, incidentally, all have occurred in the previous books of odes. ${ }^{16}$ For the purpose of this article I shall deal with the following: Horace reassessing love (identified in Odes 4.1.1-7, and further discussed in Odes 4.10, 4.11, 4.13 ), time (identified in Odes 4.1.29-36, and again in Odes 4.7, 4.10 and 4.12), politics and Augustus (implied in Odes 4.1.1-4 and discussed mainly in Odes 4.2, 4.4, 4.5, 4.14 and 4.15) and finally Horace reconsidering Horace, the poet (Odes 4.1, 4.3, 4.6, 4.8 and 4.9).

The opening ode of Odes 4 takes up the topic of love. ${ }^{17}$ Given that many readers have a rather ambivalent response to Horace's love poetry (reflecting Horace's own ambivalence, no doubt) it is surprising that Horace himself chooses a poem on love to open his first venture into lyric poetry after a lapse of 10 years, starting the poem with a wry and exceedingly ironic reference to battles long suspended (bella ... diu rursus intermissa, 4.1.1-2). This immediately calls to mind the mock battles fought with deliberately ineffectual weapons in former confrontations between the sexes (proelia virginum sectis in iuvenes unguibus acrium (1.6.16-17). Horace's reluctance to commit to this new project and these renewed battles is striking. As an introductory statement of intent this first poem determines the tone (and incidentally much of the content) of the book to follow. If reluctance for what he is doing, is imbedded in the project, this reluctance must have been overcome by something Horace could not resist. This makes an understanding of why he committed to this book at all, of crucial importance.

Taken the prominent position given to the goddess of love in the introductory poem to Odes 4 one might have expected love to feature more prominently in the rest of the collection. After a desultory initial refusal to give in to Venus's commands (iam durum imperiis, 4.1.7), Horace ends up by complying by means of his writing. In other words Horace on love is made subservient to Horace writing poetry. Only three other poems in the collection refer to love, Odes 4.10, 4. 11 and 4. 13. Furthermore, these poems all dwell on time as well, the result being that love, in each case is described as incidental to and even dependent on time.

The references to Ligurinus (4.10.5) and genae (4.10.8) link Odes 4.10 very closely to Odes $4.1{ }^{18}$ In addition Odes 4.10 is the shortest poem in the collection. It seems as if Horace also wanted to indicate visually that the time for love was short

16 These themes are illustrations of some of the basic ideas reflected in Odes 4 and which Horace reconsiders. They are by no means exhaustive.

17 Commager (1962:292) calls 4.1 a recusatio of the affections. Santirocco (1986:33) is explicit in stating that "love can stand for love poetry" and that Horace "exploits the convention" in Odes 4.1 "where he signals his return to lyric by announcing a return to love."

18 In Odes 4.1 Horace specified Ligurinus as the stubborn object of his love (4.1.33) on whose behalf a tear ran down his cheeks (manat rara meas lacrima per genas, 4.1.34). 
(and had passed). In Odes 4.1 we have already come across Horace's extreme reluctance to become involved in serving Venus. In the love poetry in this final book Horace reflects none of the urgency to achieve a better outcome $(1.19,1.23,1.25$ etc.), the calm enjoyment or a perfect setting for love $(1.17,3.28)$ or the wry acceptance of past experience $(1.5,3.9$, etc.) which were obvious in the first three books of odes. Instead in Odes 4.10 there seems to be only this empty longing for the wisdom of age when experience of life was lacking (quae mens est hodie cur eadem non puero fuit, 4.10.7). Putting this final regret of old age in the mouth of Ligurinus who at this moment is still relishing his youth (crudelis adhuc et Veneris muneribus potens, 4.10.1) reduces love merely to a factor of time. The love song has lost its urgency. It is finally and completely transformed into an expression of regret for times past. The perspective is that of someone whose time has run out, who can no longer hope for a different future.

At first glance Odes 4.11 seems to display most of the qualities associated with a love poem. The first four stanzas describe a planned celebration. The last four stanzas gently remind Phyllis, the addressee of the poem, that her unrequited love could be taken as hoping for more than is fitting (ultra quam licet sperare nefas, 4.11.29-30). In fact only the central stanza gives any indication that the celebration concerned is for Maecenas's birthday. This seems to add a totally different perspective to the poem. ${ }^{19}$ In this way Horace subtly draws in the passage of time as backdrop to a standard love triangle. Phyllis is focused on the elusive Telephus and Horace is focused on Phyllis, whom he calls the last of his loves (meorum finis amorum, 4.11.31-32). It seems as if Horace is again doing what he has done in the past (cf. Odes 1.25, 3.10): manipulating the exclusus amator topos, exchanging the urgent invocation to love for an even more urgent invocation to use time wisely. Where he previously pictured someone like Lydia (Odes 1.25) ending up (in future) as a lonely and despised old hag if she kept her excluded lover at bay the reverse seems to happen in Odes 4.11. The awfulness of old age in the present must now urgently be kept at bay with a final song (condisce modos amanda voce quos reddas: minuentur atrae carmina curae, 4.11.34-36).

The final comment on love in Odes 4.13 seems to recall odes like Odes 1.25 even more directly. What was once held out as a dire threat to Lydia, has now indeed come to pass for Lyce. The old hag of the future in Odes 1.25 is described in horrific detail in the present in Odes 4.13. Where Lydia in 1.25 would look for reluctant lovers in future non sine questu (1.25.16), arrogantly youthful lovers now look down on Lyce in the present non sine risu (4.13.27). Time has passed and the torch of love has finally been reduced to ashes (dilapsam in cineres facem, 4.13.28).

Horace's reassessment of love seems to be extremely negative. Even the last of his loves, Phyllis, ironically representing love in terms of time in finis and amorum (4.11.32), is called upon not for purposes of love, but because of her lovely voice to banish care in song. In fact one gains the overwhelming impression that the urgency

19 Contra Collinge (1961:101) who reads the reference to Maecenas's birthday (4.11.13-20) as an intrusion on the "subtle and winning conversation Horace is having with Phyllis" and even as "a mere interruption to be disregarded" (1061:116). 
of time passing has surpassed any real interest in love. More than any "academic" invocation not to spurn love when the time is right (nec dulces amores sperne puer...donec virenti canities abest morosa, 1.9.15-18) the flaming torch reduced to ashes (4.13.28) embodies how fleeting love is as a human experience.

It has started to become clear then why Odes 4 needed, not only on a technical level, to start with a love poem ${ }^{20}$ and why starting with a love poem implicitly explains why Odes 4 needed to be written. Horace had to capture in poetry the fundamental difference between anticipating or knowing that something will happen and experiencing it. This perspective on life and love (that the end [death] is actually embedded in the experience [life] from the very beginning and how that enhances reality) still needed to be added to the odes as a collection reflecting human experience.

However, it cannot be denied that Horace has always been preoccupied with carpe diem and time passing, even in a collection of odes published 10 years previously. In the introductory ode to Odes 4 a goddess forces the reluctant Horace back to work. It is not the first time that Horace had to deal with coercion or has come up with a recusatio type poem as a response to such coercion, either. ${ }^{21}$ In Ode 1.6 for instance Horace refused to write an epic account of Agrippa's achievements, but he did end up singing a lyric song about them, subtly indicating that he was capable of writing epic, but chose not to do so. In Odes 2.12 Horace at the bidding of his Muse sets aside praise for Augustus's wars (proelia Caesaris, 2.12.10) in favour of concentrating on the battle between the sexes (dulces cantus, 2.12.13-14). In Odes 4.1 Horace again describes what he is forced to do in terms of epic terminology: he is called back into battle (bella, 4.1.2). The fact that these battles are associated with Venus rather than with Mars seems to suggest a deliberate blurring of the borders between epic and lyric, enlarging as it were the scope of his love poetry. ${ }^{22}$ In the introduction to Odes 4, moreover, the poet is making it abundantly clear that he is complying with expectations, but, as he did elsewhere, on his own terms.

Another point which should not be missed right at the beginning of Odes 4 is the immediate association which springs to mind between Venus (as mother of Aeneas) and Augustus. ${ }^{23}$ Without going as far as saying that Augustus forced him to write Odes 4, Horace somehow suggests that there was little choice in the matter. In Odes 4.1 Horace describes himself as a man in a clearly unenviable position (4.1.1-8). Half of the first ode (4.1.9-28) of this new book describes the prototype whom Venus (or Augustus) should have pressured into writing songs of praise. What is interesting in this section is not only the characterization of this prototype who has to have the stomach, or as Horace calls it the iecur idoneum (4.1.12) to do what is required, but also the list of these requirements. These requirements are rather revealing namely the construction and placing of a marble effigy or statue in what turns out to be a costly

See note 12.

See Putnam (1986:36 n 1) for a review of alternative functions contributed to Odes 4.1.

Cf. how the Roman Odes (3.1-6) reflected the expanded scope of Horace's political perspectives (Thom 1998:52-66).

23 The irony of describing Venus as mater saeva (4.1.5) should not be overlooked either. 
dwelling where incense is burned and the goddess is worshipped by means of instruments, songs and dancing. Given the connection between Venus and Augustus the requirements put to Horace (that he should create a space where youth will exhalt majesty: pueri...cum...virginibus laudantes...numen...tuum, Odes 4.1.25-27) seem to suggest that Horace should do the same for Augustus. ${ }^{24}$

Horace seems to refuse Venus (and by implication Augustus) in no uncertain terms however (Odes 4.1.29-36). He lists the lyric themes like love and the hope for love relationships which no longer interest him as a poet (Odes 4.1.29-32), but admits in wry defeat that as a man he cannot escape love's power. After all, can a man prevent the occasional emotional reflex reaction - like an involuntary tear (cur manat rara meas lacrima per genas? Odes 4.1.33-34)? Finally he seems to offer an excuse for his refusal in lines which conjure up Sappho and Catullus and which reflect all the mastery of form and content of the old Horace whose eloquent tongue here falters into shameful silence (anathema to a poet) in mid speech (cur facunda parum decoro/ inter verba cadit lingua silentio? Odes 4.1.35-36). Instead of speech the poet whose whole life is words can only offer silence.

The point is surely that there is no real silence - as is clear in the final four lines which follow. Horace who stubbornly refused Venus's gentle commands (mollibus iam durum imperiis, 4.1.6-7) holds on to a stubborn Ligurinus ([te] iam captam teneo Odes 4.1.37-38); follows this elusive object of his desire, in spite of knowing that Ligurinus will remain stubborn (dure, 4.1.40) in his refusal. Horace seems to accede to Venus's commands, but not in the real world. In the case of Ligurinus he accedes to Venus only in his dreams - and how much control can one be expected to exercise over dreams, after all? Horace has chosen to comply but as before, on his own terms. ${ }^{25}$

Closely related to the whole idea of recusatio is an elaboration of the poet's role as poet. The second poem in the book makes it clear that Augustus too could not coerce the poet into doing what he was not willing to do. Again, however, the poem takes the form of a recusatio. It seems as if Horace is even more explicit in his denial to comply with praise-singing Augustus than he is in his denial to take up arms in support of Venus. In a previous poem, Ode 2.12 Horace objected to confusing the aim of lyric poetry with that which could more properly be associated with epic, giving as motivation that Maecenas, the addressee of Ode 2.12, would not want to see the harsh accounts of long wars adapted to the gentler sound of the lyre (nolis longa ...bella ... aptari citharae modis, 2.12.1,4). Horace even suggested that poetry as such might not be the medium with which to praise Augustus's battles but that it should rather be supported in pedestribus...historiis (2.12.11-12) by Maecenas himself. The structure of this poem (Odes 2.12) clearly supports Horace's position in that three out of seven stanzas are dedicated to illustrating to Maecenas just how inadequate the lyre is as medium for the praise of war. In the other four stanzas proof

\footnotetext{
24 Ironically the Carmen Saeculare published in $17 \mathrm{BC}$ did just this: creating not only the space but the very words in which the exhaltation takes place.

25 What these terms are will become progressively clearer in the section on Augustus in Odes 4.2.
} 
is given of the exact opposite: how well suited the lyre is as medium in praise of lighter themes.

If we turn to Horace's reassessment of the use of recusatio in refusing to praise Augustus, but at the same time seeming to comply with such a request we see a definite development of the idea in Odes 4.2. It is no longer enough just to say that lyric is an inadequate means for the portrayal of praise for activities inappropriate to its scope. Horace takes this as read. He now uses an example - of the poet associated with praise-poetry par excellence namely Pindar - to illustrate the point in persuasive detail. Like Odes 2.12 , Odes 4.2 is tightly structured. After an introductory stanza on the dangers of overreaching oneself, six stanzas on Pindar follow in Pindaric mode. Horace, however, does not undermine the basic point he is making. He writes this encomium of Pindar in Sapphic metre to underline his personal perspective on lyric. ${ }^{26}$ The central stanzas (4.2.25-32) of the poem include a comparison between a swan (Pindar) and a bee (Horace). ${ }^{27}$ This is a rather striking reversal of Horace's position in Odes 2.20 where Horace described his own metamorphosis into a swan a canorus ales (2.20. 15-16) in great detail. Horace's choice in Odes 4.2 is for sweetness - of form as well as substance - rather than stature, since fingo (4.2.34), the verb used here, can refer to making honey or poetry. ${ }^{28}$

In previous recusatio poetry, like Odes 1.6, Horace took the stance of not being able to write about military or political achievements, etc., but in the disclaimer gave proof of his very ability to do so, had he chosen to. In Odes 4.2 he goes a step further. He denies his ability, then proceeds to dissociate himself from the words of praise by putting such words directly into the mouth of the real praise-singer, Antonius. ${ }^{29}$ In fact, Horace draws attention to his omission by explicitly praising in his own words only the day, not the achievements concerned: o sol pulcher, o laudande, 4.2.46. ${ }^{30}$ In a group (where he uses the verb dicimus 4.2.50) he is willing to join in shouting the ritual io triumphe (4.2.49-50, as also in Epode 9.21,23, after Actium), but as an individual who sings his poetry (using the verb canam 4.2.47) he refrains very carefully from any praise-singing activities whatsoever. This is about as explicit a refusal as is possible while still seemingly complying with the original request. It is not surprising that after a recusatio addressed directly to Venus (where

26 Both Pindar and Horace were dedicated to lyric poetry but even so there are basic differences between the lyric genres associated with and generated by the two poets. Even after choosing for lyric in general (a genre which he shares with Pindar as is clear in Odes 2.20) Horace underlines his choice of one specific approach to lyric rather than another in Odes 4.2.

27 The point of the comparison between the swan and the bee is, however, that the one does not invalidate the existence of the other. Neither can one replace the other.

28 The point of interest of course lies in the fact that honey (like wine and perfume) in itself embodies the transcendence of time: the nectar harvested from flowers in the present will, in the form of honey, be available in future long after the source of the the nectar (the flowers) have gone.

29 In the previous poem, Horace did much the same. He seemingly acceded to pressure brought to bear by Venus - but only in his dreams.

30 Contra Collinge (1961:123) who ignores the implications of the stark contrast between canam (4.2.47) and dicemus (4.2.50). 
he initially refused to be drawn into the fray, but ended up acknowledging - though only in his dreams - his response to her compulsion) this second recusatio should focus on Augustus and a refusal (albeit well-motivated) to write praise poetry. In the first two odes of Odes 4 Horace therefore establishes, as a basic premise, that what follows will reflect his personal perspective and not that of someone giving way to force majeure.

It is therefore perfectly fitting that - having made his position quite clear Horace eagerly turns to his Muse in Odes 4.3. Since he was blessed by his Muse from birth there is no choice in the matter; no choice whether to write or not to write poetry. No other area of performance or field of interest could intrigue him. Both the means and the end to poetry was an ineluctable gift from the Muse. It is striking that Horace chooses to repeat the verb fingo here to indicate his writing of poetry. ${ }^{31} \mathrm{In}$ Odes 4.2.32 Horace the simple bard labours on his poems (carmina operosa, 4.2.3134) like a bee working the groves and banks of the Tiber (circa nemus uvidique Tiburis ripas, 4.2.29-30). In 4.3 those selfsame poems work diligently (fingent, 4.3.12) to put Horace on a plain with Sappho and Alcaeus (fingent Aeolio carmina nobilem, 4.3.12). At the end of the original collection of odes, Odes 3.30, Horace described himself and his poetic achievement as ex humili potens princeps Aeolium carmen ad Italos deduxisse modos (3.30 12-13). Both his origin (ex humili) and his final achievement (princeps Aeolium carmen at Italos deduxisse modos) are reassessed in Odes 4.3. Instead of a reference backwards to his humble origins, Odes 4.3 points forwards to his future fame (nobilem, 4.3.12). Instead of, like Odes 3.30 does, concentrating on the derivative aspect of the technical achievement represented by the first collection of Odes (deduxisse ad Italos modos, 3.30.13), the reassessment in Ode 4.3 puts Horace's fame down to his being the equal of the great Greek lyric poets. $^{32}$

The endings of Odes 3.30 and 4.3 make for an interesting comparison as well. In Odes 3.30 Horace asks to be crowned with Delphic laurel as a sign of his achievement. ${ }^{33}$ In Odes 1.1 at the introduction to his first collection he stated that ivy would put him on a par with the gods. In Odes 4.3 however, the foliage referred to, which indicates Horace's fame, is no longer associated with Greece and achievements measuring up to Greek originals. The dense foliage of the groves close to Rome and the Tibur will indicate Horace's fame in Roman terms and in his own right. ${ }^{34}$ This is a striking reassesment of the meaning and impact of Horace's work. It seems as if he is saying that his Roman poetry no longer needs the Greek standard to guarantee the measure of its achievement. His poetry has proven its quality and has attained its independent stature.

\footnotetext{
$31 \quad$ See note 28.

32 deduxisse seems to suggest that Greek poetry is superior to Roman in that Horace "draws" his measures "down" from the heighths like drawing water down from a higher lying area to a lower.

33 Both ivy and laurel are associated with Delphi, since Dionysus takes over from Apollo at Delphi during the winter months.

34 Cf Leach (1998:43) on how a physical image can establish the spatial framework of the poetry concernced.
} 
The measure of independence expressed in Odes 4.3 reflects quite seriously on the recusationes required in Odes 4.1 and Odes 4.2. The final stanza of Odes 4.3 states plainly that Horace's entire poetic achievement is a gift from the muse (totum munus hoc tui est, 4.3.21). It seems to function as a serious reminder to both gods and men of the independence of Horace's poetry and ironically of his own, total dependence on the Muse.

In support of his position Horace invokes Apollo to support the Roman muse directly in Odes 4.6 (Phoebe ...Dauniae defende decus Camenae, 4.6.26-27). ${ }^{35}$ Horace traces Rome's origins directly back to support from Apollo who, together with Venus, persuaded the Father of the Gods to allow Aeneas's escape and the eventual favourable founding of Rome. By establishing a firm link between Apollo's intervention then and Apollo's support now (spiritum Phoebus mihi, Phoebus artem carminis nomenque dedit poetae, 4.6.29-30) Horace suggests a linear continuation from pre-Homeric and Homeric times (stanzas 1-6) to the present day (stanzas 7-8) and even into the future when the girls and boys from the chorus addressed here will take up the song welcome to the gods (carmen ...dis amicum, 4.6.41, 43). In the original collection in Odes 3.1 Horace still concentrated on the fact that he sang carmina non prius audita (3.1.2-3). In the fourth book those previously unknown songs are now quoted and sung by the next generation. ${ }^{36}$ Horace no longer (as in 3.30) maintains that in future he will grow in the continual praise of posterity (postera... laude recens $(3.30 .7-8)$. He shows that this is already happening.

That Horace also meant Odes 4.8 as a reassessment of his previous position on poetry must be clear not only from the content but also the metre of the poem. There are only two other poems written in the First Asclepiadean namely Odes 1.1 and Odes 3.30, respectively the introduction and end to Horace's first collection of odes. In Odes 1.1 the poet still seems rather hesitant. The crown of ivy will link him to the gods, if Euterpe and Polyhymnia do not withhold their support for the flute and the lyre, the very instruments Horace needs to ply his craft. In Odes 3.30 Horace looks back with pride on his achievement. Melpomene's crown belongs to him by right (mihi Delphica lauro cinge volens, Melpomene, comam, 3.30.15-16). In Odes 4.8, however, Horace no longer focuses on himself as the writer of his poetry, but on the poetry itself. There is absolute confidence in the statement that he can write poetry and knows its worth (carmina possumus donare et pretium dicere muneri, 4.8.11-12). In this poem Horace's poetry not only immortalises the poet (as he claims in Odes 3.30), it also immortalises the poet's subject matter. Even Romulus, the founder of Rome, needed a poet to perpetuate his memory (quid foret Iliae Mavortisque puer, si taciturnitas obstaret meritis invida Romuli? 4.8.22-24). In short, Odes 4.8 is a celebration of the poet's gift. It is one thing to achieve what Augustus will celebrate in the Ludi Saeculares. It is something completely different to perpetuate the memory of that achievement. It is one thing to be famous in one's own time, but, as Pindar so clearly understood, great deeds need the art of great poets to ensure that the memory

35 Cf Barchiesi (1996:8-11) for a summary of the Greek models reflected in this ode.

36 The Carmen Saeculare performed at the Ludi was a graphic illustration of an aspect of this claim. 
of those deeds remains firmly based in the present forever. In the final analysis it is the Muse who puts the actions of mortals on another plain, the Muse who bestows the ultimate gift of immortality (caelo Musa beat, 4.8.29).

It is significant that Horace should choose to put this view of poetry across right in the middle of this fourth book of odes - the middle being, rhetorically speaking very often the point of climax in a poem or argument. Horace seems to want to underline the fact that great deeds are dependent on great poetry to transcend the normal limitations imposed by time. Great deeds have to be translated with great effort into another medium, the medium of poetry, to escape the fetters of normal reality. ${ }^{37}$ In short, in poetry mortals can transcend time.

In the very next poem Odes 4.9 Horace uses the exact same structure (with the climax occurring in the middle stanza [4.9.25-28] of the poem) to put across the exact same argument: Great achievers and great achievements sink back into oblivion if they are not remembered in poetry. In Odes 4.8 Horace dwelled on the general results or value of a tribute made in song. In 4.9 Horace illustrates this general principle with a specific example. ${ }^{38}$ In 4.8 Horace first places poetry on a par with other arts, such as painting, sculpture, and architecture which immortalised both the artist and his art. ${ }^{39}$ He proves the effectiveness of poetry by listing such household names from Roman history as Hannibal and Romulus. It is unthinkable that they might not have been known, were it not for the their celebration in poetry. Even the hero Hercules needed poetry to place him amongst the immortal gods.

After illustrating the general principle that poetry is a means by which man can transcend time Horace in Odes 4.9 turns to specific examples of this principle through the ages. From general experience it is obvious that for example Helen could not be the only woman who considered the world well lost for love; Troy was not the only city to be besieged; many heroes lived before Agamemnon etc. Horace ends this persuasive list with the chilling reminder that - once dead - there is no distinction between the brave and the cowardly. Death means oblivion, but for the the work of a sacred bard (urgentur ignotique longa nocte carent quia vate sacro, 4.9.27-28).

Since Horace concentrates on specific examples in this poem, he also uses this poem to celebrate a specific person, Lollius. ${ }^{40}$ It is soon clear, however, that Lollius is a peg on which Horace can hang his description of the happy man. In other words Horace does with Lollius what he has done with every single specific example in this poem. He modifies the reason for an individual character's fame by generalizing the activity associated with that person. Lollius is no longer a happy man specifically; he has become an example of the happy man in general. The repetition of words like

37 For the great emotional and intellectual effort required of the poet to bring this transcendance about, cf. Armstrong (1989:148): “All the great classic poets, Horace among them, are vividly aware of the gap between the artificial loyalties and enthusiasms of religion and the state, and the inadequate language of art that supports them, and behind that the tragic unintelligibility of nature, time, and death."

38 Cf Barchiesi (1996:11-13) on the close connection between Odes 4.8 and Odes 4.9.

39 As examples Horace refers to Parrhasius a famous painter and Scopas (350 BC) a renowned sculptor and architect.

40 See Putnam on Horace's choice of Lollius as someone to celebrate in poetry (1986:168-69 fn 19). 
beatum (4.9.46) and beati (4.9.49) recalls caelo Musa beat in Odes 4.8.29 directly. Activity in the present is transformed by the poet into something which transcends that which was bound by time and place.

It is striking that in both Odes 4.8 and Odes 4.9 Horace recapitulates the position expressed in Odes 3.30 at the end of the first collection of odes. In 3.30 Horace identifies himself firmly as the poet in "I have completed a monument of work" (exegi monument, 3.30.1); he places himself solidly in Italy where wild Aufidus roars (qua violens obstrepit Aufidus, 3.30.10) and he analyses his own work in terms of what he has achieved (aeolium carmen ad Italos deduxisse modos, 3.30.13-14). In Odes 4.8 Horace's poems have becomes gifts. The emphasis is no longer on the poet, but on the result of his labours. In Odes 4.9 he still refers to himself and his place of birth (natus ad Aufidum, 4.9.2) but his poems are no longer bound to a mortal poet, but are written with words which will not perish (ne...credas...interitura ...verba, 4.9.1,4).

In 3.30 the Muse, Melpomene, crowns Horace for his achievements. In 4.8 and 4.9 the Muse immortalises both achievers and achievements celebrated by his poetry. It is obvious then that when Horace reassesses his own acievements in Odes 4 he no longer has any doubts about the immortality of his own fame. He no longer has to ask Melpomene to crown him with the laurel crown; he has been crowned. He now concentrates on the results of this fame. People and deeds celebrated in his poetry will join the poet in this undying fame.

In a reassessment furthermore, it obviously pays to look not only at things which change, but also at things which stay the same. In 3.30 Horace saw his poetry as continuing a tradition of placing Rome firmly on the map of lyric poetry - a map originally drawn by the great Greek poets. In 3.30 his description of his achievement is straightforward but limited and technical: he managed to adapt one mode of expression to a different medium (aeolium carmen ad Italos deduxisse modes (3.30.13-14). At this point his claim is for recognition only. In the fourth book simple recognition makes way for the next step: appreciation of the quality and value of Horace's contribution. In 4.8 his poetry by implication both because of content and technique takes its place with other immortalizing arts such as painting etc. In 4.9 he lists a veritable who's who in Greek poetry (Homer, Pindar, Simonides, Alcaeus, Stesichorus, Anacreon, Sappho). This is the tradition that Horace now, with confidence, can claim to further in all respects.

In Horace's oeuvre, but mainly in his Odes and Epodes, we see reflected first the establishment and then the maintenance of a new order. ${ }^{41}$ The Epodes depict some of the harshest poetry associated with Horace. The Odes exemplify his most polished work. $^{42}$ This reflects not only a vast difference in tone, but also in perspective and circumstance. Many years have elapsed between the publication of the Epodes in c.

41 Obviously this is not all that is reflected in the Epodes and the Odes. I gloss over Horace's first published works (Satires 1 and 2 published in 35 and 30 BC respectively) since these deal largely with ordinary human foibles "outside time and place" as it were and not dependent on any specific political situation for their frame of reference.

42 On the difference in tone between Odes 1-3 and Odes 4, see Commager 1962:291. 
$30 \mathrm{BC}$ and Odes 4 in c. $13 \mathrm{BC}$. In that period a fundamental political change has taken place in society: the change between taking power and establishing an administration. In this type of political and social change the initial euphoria associated with a new beginning is soon replaced by a more realistic assessment of the ongoing situation. Initial anxiety at the replacement of a known situation wanes when chaos is kept at bay and a new order establishes itself over time.

It is striking then to what extent Odes 4 integrates the public and the private voice of the poet. In the final analysis it records the reconciliation between the individual and the society in which he lives. ${ }^{43}$ The realistic alternative at the end of the Epodes (to orchestrate a fortunate escape [secunda fuga, Epod. 16.66] from a violent and oppressive society and flee to a happier place) is no longer the solution. It is no longer even a viable alternative, since it has become obsolete. Fortune has finally brought a happy outcome to the war: fortuna lustro prospera tertio belli secundos reddidit exitus (4.14.37-40).

Why then did Horace need to write Odes 4? What did he need to achieve? Odes 4 seem to be remarkably clear on that, although received wisdom have not always reflected this. A reassessment was necessary, since with age Horace had developed further understanding of the world reflected in his poetry. This view did not invalidate the previous one, but it needed to be added to what was already there. To put it simply: he had new insight into what it meant to be an individual in a specific society. ${ }^{4}$ Odes 4 completes Horace's view of the world, both as an individual and as a citizen. ${ }^{45}$ The initial despair over unremitting civil war which in the Epodes encouraged whole-scale withdrawal from political life or even physical flight (Epodes 16. 36-37) gives way to a poet's uncomfortable and gradual acceptance of the establishment of the Roman State under Augustus in Odes 1-3. ${ }^{46}$ In Odes 4 we find that the poet's role as individual and as citizen has somehow become reconciled. Because the poet is absolutely free to write what and how he wants, ${ }^{47}$ his voice as

43 In Odes 3.14 much of what Augustus has achieved, is already clear, but Horace still underlines the direct link between Augustus and the consequences attached to his return (3.14.13-14), since civil strife and violent death are kept at bay in the present, but only while Caesar rules (tenente Caesare terras, 3.14.15-16). This does not yet imply lasting peace for the future, as it does in Odes 4.

44 Commager (1962:306) sums up the change of perspective reflected in Odes 4 as follows: "The steadiness with which he [Horace] watches the transformation of his ideas is itself a triumph, and the fine honesty of these poems puts them at the center of his, our, experience" - to which I would add that the poet not only watches the transformation of his ideas, but also the transformation of himself as a poet.

45 Cf. Nisbet (1984:7) who maintains that "Horace uses a poet's imagination to express genuine historical attitudes."

46 Syndikus (1973:151) points out that over time the Zeitgeist has changed to be more congenial for the poet: "Dieselbe Ordnung, die drauszen durch Augustus herrschte, war auch in Horazens Innerem eingekehrt. Eine Wahlverwandtschaft zwischen Dichter und Zeit wird deutlich."

47 His refusals of both Venus's and Augustus's attempts to bring pressure to bear on him as an individual are expressed firmly, with great elegence but very clearly. These refusals can barely be called recusationes any more, since Horace in neither case complies with the original 
individual and as citizen of the body politic can now be heard clearly. Ironically enough the poet of the Roman Odes finds himself in Odes 4 in the same position as Plato's philosopher, who has come to appreciate the well-organised state that guarantees the freedom in which to ply his trade. The individual who stood apart observing, who chose the road less travelled (via negata, 3.1.22) and who despised the vulgar (coetusque vulgares...spernit, 3.1.23-24) in Odes 1-3, becomes in Odes 4 the most eloquent spokesman for the same society that he previously scorned (custode rerum Caesare non furor civilis aut vis exiget otium, non ira, 4.15.17-19). Anger, violence and insanity, those cornerstones of epic motivation which do not appeal to the lyric poet of the Roman Odes (Odes 3.1-6, especially 3. 5, 6) will not affect peace under Augustus's reign.

It seems clear that the clarion call which cut through Horace's initial reluctance to write Odes 4 and which brought this collection into being is very directly linked to Horace's fundamental view of life: that time passes irretrievably. Politically this has meant that the Augustan state has managed to establish itself succesfully. One could still cherish some hope for a different outcome in Odes 1-3 and actively encourage this in for instance the Roman odes. Odes 4 has one urgent message: the future is here and now - and it is unexpectedly good. ${ }^{48}$

Apart from the political compunction to write Odes 4 - and Horace would have been the first to enjoy the irony of doing willingly what he apparently had refused to do under pressure throughout his life - he had no choice. Just as he originally did not have a choice either - the compulsion of the creative spirit supported by the inspiration of his Muse, ironically enough did not leave room for the type of recusatio with which he managed to sidestep previous requests for specific work or even the pressure brought to bear by Venus herself at the beginning of Odes 4. On a personal level, where carpe diem originally implied an open future and possibilities to be grasped, the 'day' has finally shortened to a mere moment, ${ }^{49}$ eroding any hope for a different outcome. ${ }^{50}$

The connection between Odes 4 and the previous odes supports the idea that the poet did feel the need to express himself again on previously identified topics, did avail himself of the opportunity for reassessment and did indeed add to what he had written previously. In short it seems as if he did indeed write quite differently in this concluding book of odes, establishing in this way a very basic reason for the existence of the collection and moreover, a reason reflected in the collection itself.

In the final analysis it seems as if Horace's reluctance to write Odes 4 was vanquished by one of his own maxims: iam satis est. Odes 1-3 no longer sufficed to

commands/requests - not even by offering an acceptable "lyric alternative" as he had previously done, in for instance Odes 1.6.

48 The Ludi Saeculares (and Horace's own Carmen Saeculare) must have spelled out the final triumph of the Augustan state.

49 See Reckford (1997:583-623) for Horace's preoccupation with time as a function of identity.

50 We have already seen, for instance, that love is not rated very highly in Odes 4, but is rather seen as being (as opposed to becoming) subservient to and dependent on time. 
reflect his view on some of the fundamental issues he had grappled with in his poetry. As a poet he was extremely reluctant to face up to all the changes brought about by the passing of time. In short the craft was still his, but the vision no longer reflected what he originally thought it did. In the new book (Odes 4), however, he could finally claim for the present what he used to be able only to claim (3.30) for the future.

\section{BIBLIOGRAPHY}

Armstrong, D 1989. Horace. New Haven: Yale University Press.

Barchiesi, A 1996. Poetry, praise, and patronage: Simonides in book 4 of Horace's Odes. Classical Antiquity 15.1:5-47.

Becker, C 1963. Das Spätwerk des Horaz. Göttingen: Vandenhoeck \& Ruprecht.

Currie, H M 1996. Horace's 'epigraphic poetry': Some comments on Odes IV. Latomus 55 (1):78-86.

Coffta, D J 1998. Programme and persona in Horace, Odes 1.5. Eranos 96 (1-2):2631.

Collinge, N E 1961. The structure of Horace's Odes. London: Oxford University Press.

Commager, S 1962. The Odes of Horace: A Critical Study. New Haven: Yale University Press.

Davis, G 1991. Polyhymnia: The rhetoric of Horatian lyric discourse. Berkeley: University of California Press.

Fraenkel, E 1957. Horace. Oxford: Clarendon Press.

Habinek, T N 1986. The marriageability of Maximus: Horace, Ode 4.1.13-20. AJP 107:407-16.

Kiessling, A and Heinze, R, with addenda by Burck, E 1958. Q. Horatius Flaccus: Oden und Epoden ( $9^{\text {th }}$ edition). Berlin: Weidmannsche Verlagsbuchhandlung.

Leach, E W 1998. Personal and communal memory in the reading of Horace's Odes, Books 1-3. Arethusa 31:43-74.

Oliensis, E 1991. Canidia, Canicula and the decorum of Horace's Epodes. Arethusa 24:107-38.

Putnam, M C J 1986. Artifices of eternity: Horace's fourth book of Odes. Ithaca: Cornell University Press.

Nisbet, R G M 1984. Horace's Epodes and history. In Woodman, T and West, D (eds), Poetry and politics in the age of Augustus, 1-18. Cambridge: Cambridge University Press.

Reckford, K J 1997. Horatius: the man and the hour. AJP 118:583-612.

Santirocco, M S 1986. Unity and design in Horace's Odes. Chapel Hill: University of North Carolina Press.

Syndikus, H P 1973. Die Lyrik des Horaz: Eine Interpretation der Oden. Band II. Drittes und viertes Buch. Darmstadt: Wissenschaftliche Buchgesellschaft.

Thom, S 1998. Lyric double talk in Horace's Roman Odes (Odes 3.1-6). Akroterion 43:52-66. 
Tully, J 1988. A reply to my critics. In Tully, J (ed.), Meaning and context: Quentin Skinner and his critics, 231-88, 326-41. Princeton: Princeton University Press. 